
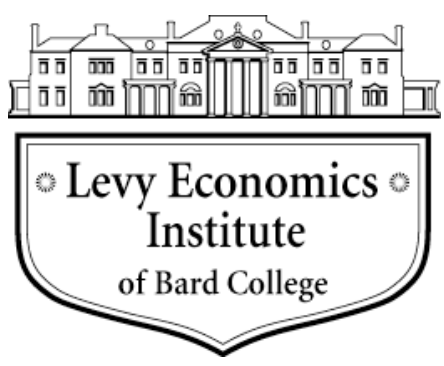

Working Paper No. 603

\title{
Does Excessive Sovereign Debt Really Hurt Growth? A Critique of This Time Is Different, by Reinhart and Rogoff
}

by

\author{
Yeva Nersisyan \\ L. Randall Wray
}

June 2010

The Levy Economics Institute Working Paper Collection presents research in progress by Levy Institute scholars and conference participants. The purpose of the series is to disseminate ideas to and elicit comments from academics and professionals.

Levy Economics Institute of Bard College, founded in 1986, is a nonprofit, nonpartisan, independently funded research organization devoted to public service. Through scholarship and economic research it generates viable, effective public policy responses to important economic problems that profoundly affect the quality of life in the United States and abroad.

Levy Economics Institute P.O. Box 5000

Annandale-on-Hudson, NY 12504-5000

http://www.levyinstitute.org

Copyright $($ C Levy Economics Institute 2010 All rights reserved 


\begin{abstract}
The worst global downturn since the Great Depression has caused ballooning budget deficits in most nations, as tax revenues collapse and governments bail out financial institutions and attempt countercyclical fiscal policy. With notable exceptions, most economists accept the desirability of expansion of deficits over the short term but fear possible long-term effects. There are a number of theoretical arguments that lead to the conclusion that higher government debt ratios might depress growth. There are other arguments related to more immediate effects of debt on inflation and national solvency. Research conducted by Carmen Reinhart and Kenneth Rogoff is frequently cited to demonstrate the negative impacts of public debt on economic growth and financial stability. In this paper we critically examine their work. We distinguish between a nation that operates with its own floating exchange rate and nonconvertible (sovereign) currency, and a nation that does not. We argue that Reinhart and Rogoff's results are not relevant to the case of the United States.
\end{abstract}

Keywords: Government Debt; Government Deficit; Sovereign Default; Reinhart and Rogoff; Economic Growth; Inflation; Modern Money

JEL Classifications: E60, E61, E62, E64, E69, E31, E32, O40 
"I think there is an element of truth in the view that the superstition that the budget must be balanced at all times [is necessary]. Once it is debunked [that] takes away one of the bulwarks that every society must have against expenditure out of control. There must be discipline in the allocation of resources or you will have anarchistic chaos and inefficiency. And one of the functions of old fashioned religion was to scare people by sometimes what might be regarded as myths into behaving in a way that the long-run civilized life requires. We have taken away a belief in the intrinsic necessity of balancing the budget if not in every year, [then] in every short period of time. If Prime Minister Gladstone came back to life he would say 'uh, oh what you have done' and James Buchanan argues in those terms. I have to say that I see merit in that view." (Paul Samuelson in Blaug, 1995)

\section{INTRODUCTION}

There is probably no hotter topic than the impact of government budget deficits and debt on long-run growth. The worst global downturn since the Great Depression has caused ballooning budget deficits in most nations, as tax revenues collapse and as governments bail-out financial institutions and attempt countercyclical fiscal policy. With notable exceptions, most economists accept the desirability of expansion of deficits over the short term, but fear possible long-term effects. The problem is said to be compounded due to structural problems with deficits in most of the advanced economies that arise from a combination of generous "entitlement" programs and aging populations, since much of the social safety net is aimed at the elderly. Hence, even those who advocate greater fiscal stimulus now argue that belt tightening will be necessary once recovery gets underway. Many believe that promised entitlements will have to be scaled back to put in place "sustainable" budgets.

But what is the relation between debt and long-term growth? And, is there a limit to how high public debt can go before the government has to default? There are a number of theoretical arguments that lead to the conclusion that higher government debt ratios might depress growth due to crowding-out effects on investment (or Ricardian equivalences) and to government's relatively inefficient use of resources. There are other arguments related to the more immediate effects of debt that rely on calculations of fiscal sustainability—relations among growth rates and government interest payments-that imply government will be forced to default or to impose a ruinous "inflation tax" that 
would slow growth. However, none of these is convincing because, as is usual in economics, theory rarely provides a definitive answer (except when spouted by onearmed economists).

To the rescue come Carmen Reinhart and Kenneth Rogoff with their monumental study (supplemented by a more recent paper) that provides empirical evidence of the relations among debt, financial crises, inflation, currency and stock market crashes, sovereign government defaults, and long-run economic growth (Reinhart and Rogoff 2009a and 2009b). They have developed a new database that covers eight centuries and sixty-six countries, although most of their book focuses on crises and defaults since 1800 . They identify 250 sovereign external defaults and 70 defaults on domestic public debt, concluding that "serial default" is the norm through history and around the globe-with almost no "default virgins" (2009a). These defaults impose large costs in terms of sustained low growth for many years, according to their analysis of the data.

From their historical analysis they concluded with some precision the prudent limit to the sovereign-debt-to-GDP ratio. They find that up to a $90 \%$ ratio, the relation between government debt and economic growth is weak, but beyond that limit growth suffers with median long-term growth falling by one percentage point and average growth falling by more. These results hold for both advanced nations and for emerging economies. However, for emerging nations - that typically borrow more from abroadthe external government debt threshold is much lower, with growth falling by two percentage points when that ratio (externally held government debt to national GDP) hits $60 \%$. Growth becomes negative at a ratio beyond 90\% (2009b). Obviously, if this result is robust, the implications for developing nations—especially—are important.

Furthermore, Reinhart and Rogoff (2009b) do not find a relation between high government debt ratios and inflation among advanced nations (except for the case of the United States), but emerging nations suffer as median inflation rises from $6 \%$ per year to $16.5 \%$ per year when they move from a lower debt ratio to a higher debt ratio. Worse, they find that countries rarely grow their way out of high debt ratios. Rather, highly indebted nations engineer default through some combination of rapid inflation or outright repudiation of the debt (2009a). Furthermore, the road to recovery after default is not 
pleasant, with years of depressed GDP, high unemployment, and diminished access to global capital markets.

Since WWII, the advanced nations had seemed to have "graduated" from serial default, but not necessarily from financial crises (indeed, a constructed composite crisis index actually indicates that the frequency of crises increased in recent years-with the current crisis the most glaring example) (Reinhart and Rogoff 2009a). The graduates enjoy a virtuous cycle because absence of default improves confidence and credit ratings, lowering interest and thus reducing growth of spending on debts. When a nation loses the confidence of its creditors, “debt intolerance” can quickly create a vicious cycle of rising interest and deficit ratios, leading to loss of access to capital markets and raising the specter of default.

They emphasize that a budget deficit, and thus growth of debt, is at least partially endogenous. Not only are interest rates a function of creditor perceptions-making interest payments endogenous - but also crises have substantial impacts on budgets. While many point to bail-out costs and use of fiscal stimulus to deal with the recessions that often accompany crises, Reinhart and Rogoff show that loss of tax revenue, combined with higher interest payments due to high risk premiums and rating downgrades, has a larger effect. Government revenue collapses as the economy slows. Crises can have long-lasting impacts on GDP and income and thus on government revenue. They find that on average, the outstanding government debt increases by $86 \%$ within three years from the start of a crisis - mostly due to revenue loss rather than to discretionary stimulus or bailouts (142). The current global crisis is no exception and government debts are growing more-or-less in line with their findings.

Should we be scared? This is not a run-of-the-mill crisis-it is easily the worst since the Great Depression. Based on the work of Reinhart and Rogoff, even if recovery has begun, we face many more years of subpar global economic performance that will produce more mountains of government debt. Some nations have already approached and even exceeded the $90 \%$ ratio and more will do so. And because this is a truly global crisis, results could be worse since it is hard to see where the global engine of growth will come from. 


\section{MISGIVINGS}

Reinhart and Rogoff (2009a) present their method as a “decidedly empirical” alternative to the more typical "narrative” approach to the study of crises. In other words, rather than studying the details of particular crises to gain an understanding of its causes and consequences in order to make more general statements, their method is to aggregate particular measures and ratios across countries and over the long sweep of history to obtain data presented in "simple tables and figures" to "open new vistas for policy analysis and research.” Presumably, they include as a goal an attempt to shed light on the current crisis, as they devote a full chapter to the "subprime crisis" and discuss the causes and likely consequences of it elsewhere in the book. Further, it is obvious that their work is widely used by those who are applying its conclusions to our situation. For these reasons, the implications of their study for our developing understanding of the current crisis are worthy of note.

They point to Kindleberger’s “Manias, Panics, and Crashes” as an example of the narrative approach to be contrasted with their own empirical analysis. It is perhaps telling that no mention is made of Galbraith’s “The Great Crash” or of any of the work of Hyman Minsky. In our view, Galbraith’s detailed “narrative” of the Great Depression stands out as a remarkably useful and highly “empirical” examination; further, a rereading of the book makes our current crisis seem like déjà vu all over again. Further, many analysts are using the work of Minsky to try to understand this crisis-indeed, it could be argued that Minsky “saw it coming” a half century ago (Wray 2009). Reinhart and Rogoff (2009a) repeat as a mantra that every boom generates the belief that "this time is different”- meaning the good times will go on forever, something the crash proves to be erroneous. This was exactly Galbraith’s argument about the 1929 crash, and

Minsky had forcefully argued that the relative tranquility of the first couple of decades of the postwar period would inevitably lead to greater risk-taking as memories of the Great Crash would fade. Ultimately this led to Bernanke’s stupendously ill-timed "great moderation” version of Irving Fisher's proclamation of a "permanently higher plateau.” Unwittingly, Bernanke gave his blessing to the most dangerous kinds of financial engineering on the argument that the world was now a much safer place because he 
believed competent central bankers had eliminated downside risk. Markets reacted in a predictable manner - greed overtook fear, as it must when losses are socialized.

It does appear that there is a lot of unnecessary originality in the Reinhart and Rogoff (2009a) book, but it is probably unintentional. Had Reinhart and Rogoff read Minsky, they would have seen his argument that a developed capitalist economy with complex financial relations generates financial crises endogenously. Reinhart and Rogoff's concept of "graduation" to a robust system immune to financial crises is inapplicable in such an economy. Minsky believed that policy can be designed to direct the economy towards more stability, but that this stability itself is destabilizing. Reinhart and Rogoff do seem to understand that speculative euphorias give way to crashes, even though each is marketed with a "this time is different" story. In other words, the empirical method they use does allow them to reject the notion that "this time is different," yet their understanding of the processes that lead a financial system up to the precipice pales by comparison to the analyses of Galbraith and Minsky. More importantly, as discussed below, it appears to us that they do not fully understand fundamental monetary operations and the conditions that make sovereign governments “default proof," even if their nongovernment sectors are still crisis-prone.

In any case, it is difficult for us to agree that their study is more useful for developing an understanding of our current crisis than are the detailed narratives, for the simple reason that they are forced to leave out details in favor of the broad brush they use. For example, let us say that one wanted to look to previous crises in Greece to look for clues to understanding its current crisis. In their "detailed" appendices, where Reinhart and Rogoff examine specific crises, two entries are devoted to Greece. There was a crisis in 1931 and the entry reads "The country defaulted on external debt and left the gold standard in place"; the second is for 1991-95 and reads "Localized problems required significant injections of public funds" (366). That is it. Admittedly it is not fair to expect the authors to provide much detail for the hundreds of crises they cover. But one could read every entry for every crisis covered and it is questionable that the accumulated knowledge obtained would be anything more than "ok, there have been a lot of crises," so that even a careful reader would have no better understanding of crises after reading all the appendices. 
But that really is not the main problem with their approach. Over the past eighthundred years (and even over the past two centuries that are the focus of the book), institutions, approaches to monetary and fiscal policy, and exchange rate regimes have changed fundamentally. The last time the U.S. government "defaulted" was in 1933. At that time, the United States operated with a "small government" that was constrained by the gold standard - a promise to convert government IOUs to gold at a fixed exchange rate. Federal government spending was only 6\% of GDP in 1933, higher than the 1929 level of 2.5\%, but not due to higher spending, but largely because GDP fell almost by half from 1929 to 1933. Today U.S. government spending typically averages a fifth to a quarter of GDP, with "transfer payments" that add another $10 \%$ or more. This transition is common among "advanced" countries, with most of them operating with governments that are closer to $50 \%$ of the economy. Do those variables matter? If so, as we will argue, simply aggregating small governments on a gold standard and large governments with nonconvertible currency and floating exchange rate regimes provides no useful information.

Now, Reinhart and Rogoff (2009a, 2009b) do argue that government debt ratios matter, which is indirectly linked to government size (a government that is just $3 \%$ of the economy is probably not going to run up a debt that is large relative to GDP). There also seems to be some understanding that the currency in which debt is issued matters-again, something that argues against simple aggregation across countries and over time. Indeed, the finding that "emerging" nations are constrained by debt ratios of $60 \%$ rather than $90 \%$ appears to be linked by the authors to emerging nations' propensity to issue foreigncurrency denominated debt and to foreign ownership of the debt (with domestic holding facing greater risk of default). They also find that when governments float their currency and limit government debt to domestic currency denomination, constraints are much looser. Indeed, that appears to be a large part of the process through which countries "graduate" from serial default to nondefaulters. We concur; we just wish they had made much more of this distinction.

The problem is that the ratios provided by Reinhart and Rogoff do not usually make such distinctions; indeed, even on a careful reading of their book it is impossible to determine which government defaults occurred under fixed exchange rates (either a gold 
standard or a peg to a foreign currency) versus a floating rate (no promise to convert at a fixed rate).

Indeed, their finding that "advanced nations" appear to "graduate" is nothing more than the transition to sovereign currencies that was completed for most developed nations with the abandonment of Bretton Woods.

So far as we can tell, there are no government defaults on debt (domestic or foreign) in the case of a floating rate currency contained in their data set. We are not sure because it is not possible to tell from their analysis. They do distinguish between “domestic debt” (presumably denominated in domestic currency) and “external debt” (in the case of emerging countries this is said to be "often" denominated in foreign currency, but no data is provided to make a distinction) $(10,13)$. In one of the appendices to the book, they list data sources for domestic public debt and under commentary they note “dollars” for some countries. Does this mean that the countries listed have adopted the U.S. dollar as their "domestic" currency? We are not sure, but if so, why would this be considered to be domestic debt?

In our view, the most important distinction one can make between what we call sovereign debt (issued by a government that does not promise conversion on demand to precious metal or foreign currency at a fixed exchange rate) and nonsovereign debt (that can include government debt issued with a promise of conversion at a fixed exchange rate) is the currency in which the debt is denominated. Interestingly, Reinhart and Rogoff rightly argue that a pegged or "heavily managed" exchange rate tends to set in motion processes that will generate crisis and default. For example, when government either explicitly or implicitly operates with a peg, there is a strong inclination by domestic residents as well as by the government itself to issue foreign currency debt whenever the domestic interest rate is higher than foreign rates. This leads to an accumulation of debts in foreign currency-essentially trading-off lower interest rates against exchange rate risk. However, for government, the trade off really comes down to lower interest rates, but with insolvency risk (Reinhart and Rogoff 2009a).

This is because the imperative of finance itself for a sovereign nation with a floating, nonconvertible currency (no promise to convert at a fixed exchange rate) is a very different matter. Reinhart and Rogoff appear to have some understanding of the 
difference: "If the exchange rate is heavily managed (it does not need to be explicitly pegged), a policy inconsistency arises between supporting the exchange rate and acting as lender of last resort to troubled institutions." (271) They go on, in the case of debt denominated in a foreign currency, "depreciation or devaluation of the currency...increases the odds of external and domestic default if the government has foreign currency-denominated debt” (272). And, finally, they note "Even an implicit guarantee of exchange rate stability can lull banks, corporations, and citizens into taking on heavy foreign currency liabilities, thinking there is a low risk of sudden currency devaluation that will sharply increase the burden of carrying such loans. In a sense, the collapse of a currency is a collapse of a government guarantee on which the private sector might have relied...” (272-3).

Yet if they had fully recognized the importance of the difference between a sovereign currency (as defined above) and a nonsovereign currency they might have used that distinction in their data sets. A government that operates with a nonsovereign currency, issuing debts either in foreign currency or in domestic currency pegged to foreign currency (or to precious metal), faces actual operational risks and does face solvency risk. However, the issuer of a sovereign currency (that is, a government that spends using its own floating and noncovertible currency) is not operationally constrained and cannot be forced into default. This is something that is recognized —at least partially—by markets and even by credit raters. For example, Japan can run government-debt-to-GDP ratios that are more than twice as high as the Reinhart and Rogoff thresholds along with extremely low interest rates on its yen denominated sovereign debt. By contrast, the 50 U.S. states, nations like Argentina that operate currency boards (in the late 1990s), or even euro nations (where the institutional structure makes them operate very much like U.S. states) face downgrades and rising interest rates with deficit ratios often much below those of Japan or even the U.S. governments. This is because a nation operating with its own currency can always spend by simply crediting bank accounts, and that includes spending on interest. Thus there is no default risk with regards to ability to pay. However, a nation that pegs or operates a currency board can be forced to default due to limits on its ability to pay what it has obligated itself to paymuch as the U.S. government abrogated its commitment to gold in 1933. 
In the next section we examine the case of the United States, which operates with a sovereign currency. We will argue that the Reinhart and Rogoff results are not relevant to the case of the United States. Unfortunately, euro nations gave up sovereign currencies when they adopted the euro; this is what allowed the possibility of sovereign default to return to nations like Greece-effectively going back to elementary school (Kelton and Wray 2009).

\section{HIGH DEBT RATIOS AND LOW GROWTH: CORRELATION OR CAUSATION?}

In a recent interview with the Wall Street Journal, Carmen Reinhart argued that the United States is not dealing with its burgeoning debt issue and that a debt downgrade might be necessary to make politicians understand the problem (Hilsenrath 2010). The Wall Street Journal has called the Reinhart and Rogoff volume (2009a) “one of the most important economics books of 2009” (Hilsenrath 2010). The book and a companion paper (Reinhart and Rogoff 2009b) have received widespread media attention and have been used by deficit hawks and doves alike to argue that the U.S. government debt buildup is not sustainable. The main finding of the paper is that when the governmentdebt-to-GDP ratio crosses the threshold of 90\%, growth slows significantly-median growth rates fall by $1 \%$ and the average falls even more. This limit is the same for developed and developing countries, however, when it comes to external debt (which is defined in their book as both public and private debt issued in a foreign jurisdiction, and usually, but not always, denominated in foreign currency), the threshold is much lower, just $60 \%$ of GDP. Once a country crosses this lower external debt threshold, annual growth declines by about $2 \%$ and at very high levels, the growth rate is cut almost in half. Many cite these numbers in reference to the situation of the United States, since about half of federal government debt is externally held; although the Japanese government debt ratio is very much higher, almost all of it is held internally and many commentators believe this to be an important distinction.

One finding for which no explanation is given in the paper is that average growth rates are higher (both for advanced and emerging economies) at midrange levels of debt 
(60-90\% of GDP) than at low levels of debt (30-60\% of GDP). If debt indeed inhibited growth, then one might expect the average growth rates to monotonically decline as the debt ratios increased, which is not the case according to their data. Second, the fact that growth rates didn't slow for some of the countries in their sample at levels of debt over 90\% - and growth was higher in some very high debt cases — should have merited some explanation. To be fair, the authors do mention that a country-specific analysis is necessary, but they fail to give any explanations for these deviations. So why do some countries grow faster at higher debt ratios while others grow more slowly? This points to the main drawback of their method, which is using average and median values across different countries and time periods to draw conclusions about debt and growth in general. It appears that in some cases a few large or outlier countries (such as the United States or Argentina) drive the results for the whole group and hence it may not be valid to try to apply those results to other countries. ${ }^{1}$ There are country-specific questions that need to be asked, but it is not clear the authors have enough data points. For example, in case of the United States, out of 216 observations of debt-to-GDP ratios, only 5 (or 2.3\% of all observations) are for levels of debt of over $90 \%$. This may not be sufficient to conclude that high debt ratios are correlated with low growth.

Most importantly, correlation doesn’t necessarily mean causation. The authors use Barro's Ricardian equivalence theory in explaining why high levels of debt are correlated with low rates of growth. As people assume that "taxes ultimately need to be raised," they spend less today and lower economic growth rates. High debts are also related to high inflation because governments are tempted to inflate away their debts (Reinhart and Rogoff 2009b). This, somehow, is supposed to lead to slow growth.

But there is another, a more plausible explanation of a correlation between high debt ratios and low growth. During a recession, the government budget automatically goes into a deficit and the debt ratio rises—a point they acknowledge. Therefore if one simply takes average rates of growth at different levels of debt, certainly there will be a negative correlation. However, causation doesn't run from debt to slow growth, but the other way around. The current recession is a very good example of this link. It is not

\footnotetext{
${ }^{1}$ One hopes that the database they have assembled might provide more detail. We have tried contacting both authors to access the database, but so far with no response.
} 
plausible to argue that the current recession in the United States was due to government debt buildup. But government debt held by the public increased from 36\% of GDP in 2006 to about 52\% of GDP by 2009 as the federal budget automatically slid further into deficit territory. As Koo (2010) argues, getting the cause and effect backwards leads to precisely the wrong policy response in what he calls a "balance sheet recession.” Just like Japan in 1990, the correct policy prescription for the United States today is more fiscal stimulus (tax cuts, spending increases, or-better-a combination of the two) to put the economy on a path to recovery. Once underway, the recovery will simultaneously restore growth and reduce the budget deficit.

\section{SOVEREIGN CURRENCY: DOES IT MATTER?}

So what is the correct way to analyze government finances? The Reinhart and Rogoff studies (2009a and 2009b) separate developed from emerging economies. In their analyses it is not always clear what kind of exchange rate regime is adopted, and whether government debts are denominated in foreign or domestic currencies. Indeed, they look to the "jurisdiction" rather than to the currency of denomination when they classify debt as domestic or foreign $(10,13)$. The important variable for them is who holds the government's debt-internal or external creditors - and the relative power of these constituencies is supposed to be an important factor in government's decision to default (2009a). This would also correlate to whether the nation was a net importer or exporter. We believe that it is more useful to categorize government debt according to the currency in which it is denominated and according to the exchange rate regime adopted. In this section we will explain why we believe that the "sovereign debt" issued by a country that adopts its own floating rate, noncovertible (no promise to convert to metal or foreign currency at a pegged rate) currency does not face default risk. Again, we call this a sovereign currency, issued by a sovereign government.

A sovereign government spends by issuing its own currency and as it's the monopoly issuer of that currency, there are no operational constraints on its ability to spend. It doesn't need to tax or issue bonds to spend; it simply does so by crediting bank accounts, operationally this is simply a matter of changing numbers on spreadsheets. On 
the other hand, countries that give up their monetary sovereignty either by pegging their currency to a metal or to another currency, or by adopting a foreign currency altogether (for example through “dollarization”), are thus constrained in their ability to finance their spending by issuing currency. A nonsovereign country that pegs its currency to another currency can only issue domestic currency up to the point where its foreign currency reserves will allow it to maintain the peg. If it issues too much of the domestic currency, a speculative attack can force the country to go off the peg, which is a default. Adoption of a peg forces a government to surrender at least some fiscal and monetary policy space-of course, constraints are less restrictive if the nation can run current account surpluses to accumulate foreign currency (or precious metal) reserves.

In the more extreme case, one in which euronations found themselves after entering the monetary union, countries give up their currency-issuing monopoly to a foreign or supranational institution, such as the ECB, and therefore are operationally dependant on financing their spending using tax and bond revenue. Effectively, members of the Eurozone are users, not issuers, of the currency. From this perspective any Eurozone country, including Germany, is more similar to a U.S. state. Hence an emerging country that retains its currency sovereignty has more domestic policy flexibility than does Greece or even Germany for that matter. We do recognize that there are constraints even on sovereign governments - they can only buy what is for sale in terms of their own currency, for example. And too much spending can drive inflation, but they do not face solvency constraints in their own currency.

Why isn’t Japan paying high interest rates or facing debt crises despite its high debt-to-GDP ratio-a ratio much higher than that of Greece? Precisely because the Japanese "debt" is denominated in its own currency, the monopoly issuer of which is the Japanese government. Japan’s “exceptionalism” in comparison with Greece is not that its debt is held by Japanese citizens as Reinhart and Rogoff argue (2009b). A sovereign government services its debt—whether held by foreigners or domestically — in exactly one way: by crediting bank accounts. There is no more risk of involuntary default on foreign-held Japanese sovereign debt than on domestic-held Japanese sovereign debt—in neither case can the Japanese government be forced to default. 
The Rogoff-Reinhart classification exposes their incomplete understanding of what government debt is. When a country operates on sovereign currency, it doesn't need to issue bonds to "finance" its spending. Issuing bonds is a voluntary operation that gives the public the opportunity to substitute their non-interest-earning government liabilitiescurrency and reserves at the central bank-into interest-earning government liabilities, such as treasury bills and bonds, which are credit balances in securities accounts at the same central bank. But if one believes that the government needs to borrow to spend, then who owns the bonds or who is willing to buy the bonds becomes an important issue. From this perspective, a country can be shut out of international capital markets or even domestic capital markets if it fails to honor its liabilities. If one understands that bond issues are a voluntary operation by a sovereign government, and that bonds are nothing more than alternative accounts at the same central bank operated by the same government, it becomes irrelevant for matters of solvency and interest rates whether there are takers for government bonds and whether the bonds are owned by domestic citizens or foreigners.

Some might object that default is always to some degree a voluntary event-a point made by Reinhart and Rogoff in their book (ch. 4). Even nonsovereign governments (as we define them) in some sense choose when to default. For example, the U.S. government chose the day in 1933 on which it would default on its commitment to deliver gold, but it could have defaulted earlier or somewhat later. Eventually it could have been forced to default — when it finally exchanged its last ounce of gold for dollars - but it actually defaulted long before that point was reached. That is the usual situation: the country is losing foreign currency (or metal) reserves at a rapid pace and faces escalating interest rates, at which point it abandons convertibility, suspends payment or forces a haircut, and often redenominates debt in domestic currency. In most cases, the government could have postponed default and might even have been able to avert default through imposition of draconian austerity that would generate a trade surplus of sufficient size. So we do accept the Reinhart and Rogoff argument that governments in some sense choose default as the lesser of two evils. However, in the case of sovereign government debt, the government always has the wherewithal to make all payments as they come due-without demanding higher taxes from residents and without 
generating a trade surplus. It is still possible that a sovereign government might simply choose to default on its debt-perhaps for political reasons-but this does not appear to be an empirically important phenomenon. In the Reinhart and Rogoff book (110), which claims to have exposed 70 cases of domestic default, we can't find a single case when a country that issues its own currency and doesn't peg it to another currency or metal defaulted on its debt.

Another problem with the Rogoff and Reinhart book (2009a) and the paper (2009b) is that they lump together public and private external debts following the logic that "debt is debt." This further demonstrates an incomplete understanding of the difference between a private sector entity and the government. When a private entity goes into debt, its liabilities are another entity's asset. Netting the two, there is no net financial asset creation. When a sovereign government issues debt, it creates an asset for the private sector without an offsetting private sector liability. Hence government issuance of debt results in net financial asset creation for the private sector. Private debt is debt, but government debt is financial wealth for the private sector. A buildup in private debt should raise concerns because the private sector cannot run persistent deficits. But the government, as the monopoly issuer of its own currency, can always make payments on its debt by crediting bank accounts—and those interest payments are nongovernment income, while the debt is nongovernment assets. Said another way, Ponzi is when one must borrow to make future payments. For government with a sovereign currency, there is no imperative to borrow, hence it is never in a Ponzi position.

Reinhart and Rogoff (2009b) report that growth deteriorates significantly at external debt levels of over $60 \%$ and that most default on external debt in emerging economies since 1970 s has been at $60 \%$ or lower debt-to-GDP ratios (which is the Maastricht criteria). While this might be a surprising finding for them, it should be clear why countries are less tolerant to external debt as it is often denominated in foreign currency. Again, since they lump together private and public debts it is hard to know how much of it is private and how much is public debt, and how much of the public debt is sovereign (domestic nonconvertible currency) versus how much is nonsovereign (convertible to foreign currency). 
With a sovereign currency, the need to balance the budget over some time period determined by the movements of celestial objects or over the course of a business cycle is a myth, an old-fashioned religion. When a country operates on a fiat monetary regime, debt and deficit limits and even bond issues for that matter are self-imposed, i.e., there are no financial constraints inherent in the fiat system that exist under a gold standard or fixed exchange rate regime. But that superstition is seen as necessary because if everyone realizes that government is not actually constrained by the necessity of balanced budgets, then it might spend “out of control," taking too large a percent of the nation's resources. Paul Samuelson saw merit in that view:

"I think there is an element of truth in the view that the superstition that the budget must be balanced at all times [is necessary]. Once it is debunked [that] takes away one of the bulwarks that every society must have against expenditure out of control. There must be discipline in the allocation of resources or you will have anarchistic chaos and inefficiency. And one of the functions of old fashioned religion was to scare people by sometimes what might be regarded as myths into behaving in a way that the long-run civilized life requires. We have taken away a belief in the intrinsic necessity of balancing the budget if not in every year, [then] in every short period of time. If Prime Minister Gladstone came back to life he would say 'uh, oh what you have done' and James Buchanan argues in those terms. I have to say that I see merit in that view." (Paul Samuelson in Blaug, 1995)

Sovereign governments do not face any financial constraints and cannot run out of their own currency as they are the monopoly issuers of that currency as Reinhart and Rogoff seem to understand $(119,180)$. They make any payments that come due, including interest rate payments on their debt and payments of principal, by crediting bank accounts meaning that operationally they are not constrained on how much they can spend. As bond issues are voluntary, a sovereign government doesn't have to let the markets determine the interest rate it pays on its bonds either. Countries like Greece, which give up their monetary sovereignty, do face financial constraints and are forced to borrow from capital markets at market rates to finance their deficits. As the Greek experience shows, this monetary arrangement allows the markets and rating agencies (or other countries, in case of Greece) to dictate domestic policy to a politically sovereign country. 
There are only passing references to the currency in which the debt is denominated in the Reinhart and Rogoff research (2009a and 2009b), creating the impression among readers that this is not an important factor for debt sustainabilitywhile it's actually the most important factor. Governments cannot be forced to default on sovereign debt. In their book, they document that during defaults governments tend to convert external currency denominated liabilities into domestic currency denominated liabilities. This happened in Argentina as well as in Mexico. So if the currency in which the debt is denominated is not important, why do countries do this? Yes, that is a default, but it gets the debt into a currency that the government can create through "keystrokes"crediting bank accounts. They also mention that external debt "thresholds are higher for advanced economies that issue most external debt in their own currency” (2009b). No explanation is provided by them, but it should now be clear that sovereign nations that issue their own floating, nonconvertible currency cannot be forced to default on their own currency debt.

To conclude this discussion, we emphasize that public debt denominated in a foreign currency can create serious problems for the government. When a government borrows in foreign currency, even low levels of indebtedness can be unsustainable since the government is not able to issue that foreign currency to meet its debt obligations. As countries need to earn foreign exchange from exports, a sudden reversal in export conditions can render the country unable to meet its foreign debt obligations. The same applies to the private sector. When households or firms take on debts denominated in foreign currency, this creates a fragile situation and the drying up of the sources of foreign exchange will cause widespread debt defaults, possibly leading to a financial crisis. For this reason, governments should never issue debt instruments denominated in foreign currency; prudent private market participants probably should not, either, but if they do their government should refuse to take over the foreign currency debt. If the government issues debt in its own currency, it doesn't matter who holds its debtforeigners or its own citizens. It can always make payments on its debt just like it makes any other payments, by crediting bank accounts, technically issuing new money. But if government takes on private debt in foreign currency, it suddenly opens itself to solvency risk. 
What about inflation? Reinhart and Rogoff (like most economists) worry that if the government as monopoly issuer of the currency simply spends by issuing more currency, this will result in run-away inflation (180). Yes, too much spending by government can be inflationary. That is not contested. This is the point made by Samuelson in the quote above. Once an economy reaches full employment, any further spending (by government, households, firms, or foreigners) will generate inflation (unless nongovernment spending is somehow reduced). And bottlenecks can produce inflation even before full employment. But when an economy is operating well below full capacity, lower taxes or more government spending (with proper controls on prices paid by government) will not be inflationary. We are here instead addressing questions of solvency, default, and "sustainability." The point we are making is a simple one: a sovereign government cannot be forced to default on debt denominated in its own currency. Yes, too much spending is inflationary, but cutting taxes or spending by crediting bank accounts when the economy has excess capacity is not going to generate inflation from excess demand and it is not going to lead to default by a sovereign government on its promises.

While some do call inflation a default (and Reinhart and Rogoff do just that in their book), we believe this is completely unjustified in the case of a sovereign currency. Government does not promise to convert its currency to a basket of commodities, so a rising price of that basket is not legally a default. In the case of a gold standard (which we define as a nonsovereign currency), a devaluation of the currency is technically a default - the holder of the government's currency cannot exchange it for the previously agreed-upon quantity of gold. But the U.S. government no longer makes any such promise, nor does it promise to convert its currency to a fixed basket of commodities. Obviously, if inflation were a default, then virtually all governments are defaulting continuously since there is inflation in almost all countries in almost all years since WWII. ${ }^{2}$ We do not find such a definition useful.

\footnotetext{
${ }^{2}$ Reinhart and Rogoff define inflation crises as inflation rates of $20 \%$ or more per annum.
} 


\section{CONCLUSIONS}

Today unemployment is near $10 \%$ and the broader measure of labor underutilization is around $17 \%$, yet public debate focuses on how to lower the budget deficit rather than on policy to lower unemployment. Mainstream economists-in many cases, the same ones who helped to create this crisis - are still out there giving advice about reducing the "huge" deficit and debt. The majority of economists that talk about deficits and debt have little understanding of the modern monetary regime in which the United States has been operating for the past four decades. It is sufficient to look at the CBO Director's Letter to a Seventh Grader to realize that even the nonpartisan office that is most respected when it comes to deficit and debt issues misunderstands the causes and consequences of sovereign budget deficits. Most "experts" confuse solvency with some measure of "sustainability" based on rather arbitrary deficit-to-GDP and debt-to-GDP ratios. These ratios might be applicable under a fixed exchange rate regime or a gold standard, but they are not relevant for a country with its own nonconvertible currency.

When it comes to a sovereign government's budget deficit and debt there are no magic numbers or ratios that are relevant for all countries and all times. There are no thresholds that once crossed will be unsustainable or lead to lower growth. The government's budget balance in most advanced nations is highly endogenous and is merely the other side of the coin of the nongovernment sector's balance. The public deficit is the result of the private sector's willingness to net save and net import.

Modern monetary theory (Wray 1998) is often interpreted as claiming that there is no real limit to the government's ability to spend or that the government should run up deficits. Of course there is a limit to the government's ability to spend and of course it shouldn't spend an infinite amount. Yet, the sovereign government is not constrained financially, which means that it can never face a solvency issue. Still, it is certainly constrained in real terms meaning it can face another kind of sustainability issue: how much of the nation's resources ought to be mobilized by government? Given the level of resources that the nongovernment sector wants to mobilize, how large should the government's deficit be to mobilize the rest? 
More than five decades ago, Abba Lerner gave the answer to this question. If there are involuntarily unemployed (we would add underemployed) people it means the deficit is too low. The government should either cut taxes or increase spending. It is certainly debatable which one is a better policy, but that's beyond the scope of this paper. When is the deficit too large? When it's over 3\%, 7\%, 10\%? Again, there is no magic number and anyone who comes up with a universal number simply misunderstands the modern monetary regime and macroeconomics. In opposition to magic, Lerner proposed "functional finance"-the notion that the federal government's budgetary outcome is of no consequence by itself, but rather, what is important is the economic effects of government spending and taxing. When total spending in the economy, including government spending, is more than what the economy is able to produce when employed at full capacity, the government should either lower its spending or raise taxes. A failure to do so will lead to inflation. So inflation is the true limit to government spending not lack of financing. Government debt is merely the result of government deficit and hence the same applies to debt as well. 


\section{REFERENCES}

Blaug, M. 1995. The movie “John Maynard Keynes: Life/Ideas/Legacy.”

Hilsenrath, J. 2010. "Q\&A: Carmen Reinhart on Greece, U.S. Debt and Other 'Scary Scenarios.” The Wall Street Journal, February 5.

Kelton, S., and L.R. Wray. 2009. “Can Euroland Survive?” Public Policy Brief No. 106. Annandale-on-Hudson, NY Levy Economics Institute.

Koo, R. 2010. "Why inflation might not be around the corner for U.S. and Europe." Nomura Securities Co Ltd, Tokyo, Economic Research—Flash Report, April 27 www.nomura.com/research

Minsky, H.P. 2008. Stabilizing an Unstable Economy, first edition. New York: McGrawHill.

Reinhart, C., and K. Rogoff. 2009a. This Time is Different: Eight Centuries of Financial Folly. Princeton, NJ: Princeton University Press.

Reinhart, C., and K. Rogoff. 2009b. “Growth in a Time of Debt.” paper prepared for American Economic Review Papers and Proceedings, December 31 (draft).

Wray, L.R. 2009. "The rise and fall of money manager capitalism: a Minskian approach.” Cambridge Journal of Economics 33: 807-828.

Wray, L.R. 1998. Understanding Modern Money: The Key to Full Employment and Price Stability. Cheltenham, UK: Edward Elgar. 